\author{
Abstracta Iranica \\ Abstracta Iranica Revue bibliographique pour le domaine irano-aryen \\ Volume 32-33 | 2013 \\ Comptes rendus des publications de 2009-2010
}

\title{
Rudi Matthee. Was Safavid Iran an empire?
}

\section{Andrew Newman}

\section{(2) OpenEdition}

\section{Journals}

Electronic version

URL: http://journals.openedition.org/abstractairanica/40671

DOI: 10.4000/abstractairanica.40671

ISSN: 1961-960X

\section{Publisher:}

CNRS (UMR 7528 Mondes iraniens et indiens), Éditions de l'IFRI

Printed version

Date of publication: 1 December 2013

ISSN: 0240-8910

\section{Electronic reference}

Andrew Newman, «Rudi Matthee. Was Safavid Iran an empire? », Abstracta Iranica [Online], Volume 32-33 | 2013, document 248, Online since 01 July 2016, connection on 27 September 2020. URL : http://journals.openedition.org/abstractairanica/40671; DOI : https://doi.org/10.4000/ abstractairanica.40671

This text was automatically generated on 27 September 2020.

Tous droits réservés 


\title{
Rudi Matthee. Was Safavid Iran an empire?
}

\author{
Andrew Newman
}

\section{REFERENCES}

Rudi Matthee. « Was Safavid Iran an empire? ». Journal of the Economic and Social History of the Orient, vol. 53, 2010, p. 233-265.

1 The author argues that Safavid Iran enjoyed a "cohesion and coherence" that made it more than a mere "gunpowder empire" (pace Marshall Hodgson, The venture of Islam, vol. 3, The gunpowder empires and modern times, Chicago, 1974) and allowed it "to function as an empire in spite of exiguous economic resources and the limitations of ideological underpinnings". However the loss of these in the later years furthered the processes of decline in the early 18 th century.

2 This article is divided into six parts, including an introduction and conclusion. A long bibliography has been appended. Matthee starts by reviewing the literature on empires of the time, noting that most recent studies focus on the Ottoman polity as the era's empire par excellence to which the term can rightly be applied. He compares the case for a Safavid "empire", noting, for instance, that there was no fixed economic or political center and that genealogical claims were problematic. He asks whether what he calls the "Safavid state" had "any imperial credentials. Was it capacious enough, and were its claims to sovereignty sufficiently universal for it to qualify as an empire?" Despite Safavid Iran's comparatively homogeneous religious composition, its ethnic make-up was quite diverse. It had "ideological underpinnings", a conception of a "greater Iran" for example, that were linked to an identification with the Twelver faith during this period. A sense of "Persian culture", along with developments in literature and especially poetry, was an additional element in this discourse. The meaning of the ruler and his status as a "universal" leader were also part of this ideology. Matthee points to the "imperial heights" reached in architecture, commerce and politics, in particular 
the territorial gains under 'Abbās I, as well as the pragmatic, inclusive, accommodating tolerance with which power was exercised from the center; but he argues that these apogees were reached early on and never surpassed. Thereafter, the forces of decline accentuated the failure to move past, or expand on, these earlier strengths.

3 This topic is timely. In 2010 Stephen Dales' The Muslim empires of the Ottomans, Safavids, and Mughals (Cambridge) came out; and in 2011 Douglas Streusand's Islamic gunpowder empires: Ottomans, Safavids, and Mughals (Boulder). Several other projects on Middle Eastern empires are in the works. Of the four extant discussions (including Hodgson's) on the Safavids, Matthee's is the most useful. It provides a working definition of empire and then judges the Safavids accordingly. Nevertheless, since all four adopt the idea of a "Safavid decline", the discussion in each is distinctly, perhaps ultimately, teleological in tone.

\section{AUTHORS}

\section{ANDREW NEWMAN}

Université d'Edimbourg 